\title{
Cinnamaldehyde and $\alpha$-terpineol as an alternative for using as denture cleansers: antifungal activity and acrylic resin color stability
}

\author{
Cinamaldeído e $\alpha$-terpineol como uma alternativa para uso como limpadores de prótese: atividade \\ antifúngica e estabilidade de cor da resina acrílica \\ Cinamaldehído y $\alpha$-terpineol como alternativa para su uso como limpiadores de prótesis: actividad \\ antifúngica y estabilidad del color de la resina acrílica
}

Received: 03/03/2021 | Reviewed: 03/07/2021 | Accept: 03/08/2021 | Published: 03/16/2021

Loyse Martorano-Fernandes

ORCID: https://orcid.org/0000-0002-5995-5085

Federal University of Paraíba, Brazil

E-mail: loyse_martorano@hotmail.com

Nadiny Cezar Rodrigues

ORCID: https://orcid.org/0000-0001-6351-1869

Federal University of Paraíba, Brazil

E-mail: nadinycrodrigues@outlook.com

Natanael Victor Furtunato Bezerra

ORCID: https://orcid.org/0000-0002-5348-3363

Federal University of Paraíba, Brazil

E-mail: natanaelvictorfurtunato@gmail.com

Maria Heloisa de Souza Borges

ORCID: https://orcid.org/0000-0003-3038-0908

Federal University of Paraíba, Brazil

E-mail: heloisaboorges@gmail.com

Yuri Wanderley Cavalcanti

ORCID: https://orcid.org/0000-0002-3570-9904

Federal University of Paraíba, Brazil

E-mail: yuri.wanderley@yahoo.com.br

Leopoldina de Fátima Dantas de Almeida

ORCID: https://orcid.org/0000-0001-5997-6612

Federal University of Paraíba, Brazil

E-mail: leopoldinalmeida@hotmail.com

\begin{abstract}
Objective: here was investigated the potential of phytoconstituents as cinnamaldehyde and $\alpha$-terpineol as denture cleansers, which was evaluated the antifungal activity, also their effect on the color change of the poly(methyl)methacrylate (PMMA). Methodology: Candida albicans biofilms were formed on PMMA specimens and exposed a 10 minutes daily treatment with cinnamaldehyde $(10 \mathrm{mg} / \mathrm{mL}), \alpha$-terpineol $(10 \mathrm{mg} / \mathrm{mL}), \mathrm{NaCl} 0.9 \%$, and $\mathrm{NaClO} 1 \%$. Biofilms were collected, then analyzed the cell viability (CFU/ $\mathrm{mL}$ ), cell metabolism (MTT), and roughness. Moreover, the color variation of the specimens during seven and 14 days was checked. Kruskal-Wallis, Mann Whitney, and ANOVA one-way were applied $(\alpha<0.05)$. Results: cinnamaldehyde and $\alpha$-terpineol decrease the number of viable cells compared to $\mathrm{NaCl} 0.9 \%$ by $76 \%$ and $83.2 \%$, respectively $(\mathrm{p}<0.05)$. Both substances reduce biofilm metabolism by around $70 \%(\mathrm{p}<0.05)$. Also, the phytoconstituents showed low biofilm roughness, similar to $\mathrm{NaClO}(p>0.05)$, without changing the color of the acrylic resin ( $p>0.05)$. Conclusion: cinnamaldehyde and $\alpha-$ terpineol, at a concentration of $10 \mathrm{mg} / \mathrm{mL}$, shows antifungal activity on C. albicans biofilms free from PMMA surface changes. From a clinical viewpoint, these substances have a strong potential to be incorporated into denture cleansers solutions.
\end{abstract}

Keywords: Candida albicans; Biofilms; Stomatitis, Denture; Denture cleansers; Phytotherapy.

\section{Resumo}

Objetivo: foi investigado o potencial dos fitoconstituintes cinamaldeído e $\alpha$-terpineol como potenciais limpadores de prótese dentária, no qual foi avaliado a atividade antifúngica, bem como o efeito dos tratamentos na mudança de cor do poli(metil)metacrilato (PMMA). Metodologia: Biofilmes de Candida albicans foram formados sobre espécimes de PMMA e expostos a um tratamento diário por 10 minutos com cinamaldeído $(10 \mathrm{mg} / \mathrm{mL})$ e $\alpha$-terpineol $(10 \mathrm{mg} / \mathrm{mL})$, $\mathrm{NaCl} 0,9 \%$, e $\mathrm{NaClO} 1 \%$. Os biofilmes foram coletados e realizadas as análises de viabilidade celular (UFC/ $\mathrm{mL}$ ), metabolismo celular (MTT) e rugosidade do biofilme. Adicionalmente, foi checada a variação de cor dos espécimes 
durante sete e 14 dias. Os testes de Kruskal-Wallis, Mann Whitney, e ANOVA um fator foram utilizados $(\alpha<0,05)$. Resultados: cinamaldeído e $\alpha$-terpineol diminuíram o número de células viáveis, quando comparado ao $\mathrm{NaCl} 0,9 \%$, em $76 \%$ e 83,2\%, respectivamente ( $\mathrm{p}<$ 0,05). Ambas substâncias reduziram o metabolismo do biofilme em aproximadamente $70 \%(\mathrm{p}<0,05)$. Além disso, os fitoconstituintes testados resultaram um biofilme pouco rugoso, similar a $\mathrm{NaClO}(\mathrm{p}>0,05)$, sem modificar a cor da resina acrílica dos espécimes ( $>$ > 0.05). Conclusão: cinamaldeído e $\alpha$-terpineol, nas concentrações de $10 \mathrm{mg} / \mathrm{mL}$, apresentaram atividade antifúngica em biofilmes de C. albicans sem alterar a cor da resina acrílica. De um ponto de vista clínico, essas substâncias possuem um forte potencial para serem incorporadas em soluções para limpeza de próteses dentárias.

Palavras-chave: Candida albicans; Placa dentária; Estomatite sob prótese; Higienizadores de dentarura; Fitoterapia.

\section{Resumen}

Objetivo: se investigó el potencial de los constituyentes fitoquímicos cinamaldehído y $\alpha$-terpineol como potenciales limpiadores de prótesis dentales, en el que se evaluó la actividad antifúngica, así como el efecto de los tratamientos sobre el cambio de color del poli (metil) metacrilato (PMMA). Metodología: Se formaron biopelículas de Candida albicans en muestras de PMMA y se expusieron a un tratamiento diario durante 10 minutos con cinamaldehído (10 mg / ml) y $\alpha$-terpineol (10 mg / ml), $\mathrm{NaCl}$ al $0,9 \%$ y NaClO al $1 \%$. Se recolectaron biopelículas y se analizó la viabilidad celular (UFC / mL), el metabolismo celular (MTT) y la rugosidad del biofilm. Además, se verificó la variación de color de las muestras durante siete y 14 días. Se utilizaron las pruebas de Kruskal-Wallis, Mann Whitney y ANOVA unidireccional $(\alpha<0,05)$. Resultados: el cinamaldehído y el $\alpha$-terpineol disminuyeron el número de células viables, en comparación con $\mathrm{NaCl}$ al $0,9 \%$, en un $76 \%$ y 83,2\%, respectivamente (p <0,05). Ambas sustancias redujeron el metabolismo de la biopelícula en aproximadamente un $70 \%$ ( $<<0,05)$. Además, los fitoquímicos probados dieron como resultado un biofilm ligeramente rugoso, similar al $\mathrm{NaClO}$ ( $\mathrm{p}>0.05)$, sin cambiar el color de la resina acrílica de las muestras ( $\mathrm{p}>0.05$ ). Conclusión: el cinamaldehído y el $\alpha$-terpineol, a concentraciones de $10 \mathrm{mg} / \mathrm{mL}, \mathrm{mostraron}$ actividad antifúngica en biofilms de $C$. albicans sin alterar el color de la resina acrílica. Desde un punto de vista clínico, estas sustancias tienen un gran potencial para incorporarse en soluciones para la limpieza de prótesis dentales.

Palabras clave: Candida albicans; Placa dental; Estomatitis subprotérica; Limpiadores de dentadura; Fitoterapia.

\section{Introduction}

Denture stomatitis is a disease characterized as hyperemia and hyperplasia in the palatal mucosa under the removable prosthesis (Hannah et al., 2017). This condition is caused by biofilm mainly composed by Candida albicans, an opportunistic fungus that can form a robust architecture of pathogenic cells in the prosthesis surface (Gendreau \& Loewy, 2011). The prosthesis surface is formed by poly(methyl)methacrylate (PMMA). This acrylic resin has structural porosities in which the biofilm can penetrate and be a source of infection (Figuerôa et al., 2018). In cases of this biofilm not removed from the surface, C. albicans can violate the oral epithelium barrier to cause denture stomatitis (Mayer, Wilson \& Hube, 2013). Thus, cleaning the dental prosthesis surface is the first step for preventing and treating denture stomatitis (Pellizzaro et al., 2012).

Biofilm can be removed using brushing or denture cleaners, such as sodium hypochlorite $(\mathrm{NaClO})$ or alkaline peroxide, consisting of the dental prosthesis's immersion in these diluted chemical solutions (Pellizzaro et al., 2012; Duyck et al., 2016). Although these substances are widely used to remove the biofilm, they cause harmful changes in the PMMA surface, increasing the surface roughness and changing the material's color (Pellizzaro et al., 2012; Paranhos et al., 2013; Kurt et al., 2018). Thereby, natural products have been studied as potential denture cleaners (Almeida et al., 2016; Arruda et al., 2018; de Souza et al., 2019).

Natural agents have chemical compounds known as phytoconstituents, which have target action for treating and preventing biofilm-related diseases (Mehta et al., 2015). Some of these compounds are cinnamaldehyde and $\alpha$-terpineol, which are derivated from the cinnamon bark and the Melaleuca alternifolia, respectively (Doyle \& Stephens, 2019; de Groot \& Schmidt, 2016). These phytoconstituents demonstrated an antifungal effect against C. albicans (Ramage et al., 2012; Taguchi et al., 2012; Bakhtiari et al., 2019). Studies have shown that these substances in planktonic cultures can disrupt the cell membrane of $C$. albicans leading to fungus death (Taguchi et al., 2012; Ramage et al., 2012). However, our knowledge is still unclear about evaluating cinnamaldehyde and $\alpha$-terpineol as denture cleaners for Candida biofilms formed on PMMA surfaces. Besides, the literature lacks evidence regarding the color change of the acrylic resin after using these substances. Therefore, 
this in vitro study aimed to evaluate the antifungal activity of cinnamaldehyde and $\alpha$-terpineol as denture cleaners of $C$. albicans biofilm, and their effect on the color change of the poly(methyl)methacrylate.

\section{Methodology}

\section{Experimental design}

This in vitro study followed an inductive method (Pereira et al., 2018). Poly(methyl)methacrylate (PMMA) standardized discs were randomized into four groups and treated with: $0.9 \% \mathrm{NaCl}$ (positive control), $\mathrm{NaClO} 1 \%$ (negative control), cinnamaldehyde $(10 \mathrm{mg} / \mathrm{mL})$ and $\alpha$-terpineol $(10 \mathrm{mg} / \mathrm{mL})(\mathrm{n}=12$, for each group). On the discs were formed salivary acquired-pellicle and C. albicans biofilm as well. Subsequently, the discs were immersed in the solutions for 10 minutes, repeating this process once a day for three consecutive days. After 96 hours of biofilm formation, the counting of colony-forming unit (CFU/mL), cell metabolism (MTT), and surface roughness analyses were performed. The color variation analysis was conducted at the beginning of the experiment, after seven and fourteen days. All analyzes were performed in triplicate.

\section{PMMA specimen preparation}

PMMA specimens (10 mm diameter x 2mm thick) were prepared using heat-polymerized acrylic resin (QC 20, Dentsply) according to the manufacturer instructions and a previous investigation (Cavalcanti et al., 2016). The resin was inserted at the doughy stage and molded into a disc-shaped metallic device. Then, the acrylic resin was polymerized for $1 \mathrm{~h}$ at $100{ }^{\circ} \mathrm{C}$. The specimens were removed from the metallic device, trimmed, and polished with abrasive paper (600 grit). The baseline surface roughness was determined by CCI MP optical perfilometry (CCI MP Taylor Hobson Profilometer) for each disc. Before the treatments with the substances, the PMMA surfaces were sterilized with ethylene oxide.

\section{Cinnamaldehyde and $\alpha$-terpineol solutions preparation}

Based on results of Minimal Inhibitory Concentration (MIC) (data not shown), cinnamaldehyde (Sigma-Aldrich, USA), and $\alpha$-terpineol (Sigma-Aldrich, USA) were used in a concentration of $10 \mathrm{mg} / \mathrm{mL}$. These substances were diluted in $\mathrm{NaCl} 0.9 \%$, and Tween 80 was used as an emulsifier in both solutions.

\section{Microbial strains and growth conditions}

Candida albicans (ATCC 90028) reference strain was reactivated in Sabouraud Dextrose Agar (Difco, Detroit, USA) and incubated for 24 hours at $37^{\circ} \mathrm{C}$. Subsequently, three to five colonies were collected and suspended in $5 \mathrm{~mL}$ of $\mathrm{NaCl} 0.9 \%$. Then, cells' concentration was determined on the spectrophotometer at $600 \mathrm{~nm}$, in which cell density was absorbed in 0.1 , equivalent to a concentration of $1.0 \times 10^{6} \mathrm{CFU} / \mathrm{mL}$. The inoculum's final adjustment was performed in RPMI 1640 medium (Inlab Diagnostic, Brazil).

\section{Preconditioning with artificial saliva and biofilm assay}

PMMA discs were immersed in $500 \mu \mathrm{L}$ of artificial saliva composed of $1 \%$ carboxymethyl (w/v); $0.0084 \%$ sodium chloride (w/v); $0.12 \%$ potassium chloride (w/v); $0.0342 \%$ potassium phosphate $(\mathrm{w} / \mathrm{v}) ; 0.0146 \%$ calcium chloride (w/v), and $0.052 \%$ magnesium chloride (w/v) (Martins et al., 2018); following by incubation at $37^{\circ} \mathrm{C}$ for 60 minutes (MartoranoFernandes, Cavalcanti \& Almeida, 2020). Afterward, the discs were randomly and individually allocated into 24 -well plates with $500 \mu \mathrm{L}$ of $C$. albicans inoculum to biofilm development for 24 hours under microaerophilia. Subsequently, the culture medium was removed, and the discs were immersed in the solutions for 10 minutes, once a day for three consecutive days. 
After 96 hours of biofilm development, the tests were performed.

\section{Cell viability analysis}

PMMA discs were transferred to microtubes with $1.0 \mathrm{~mL}$ of sterile $\mathrm{NaCl} 0.9 \%$ and submitted an agitation in a vortex for 60 seconds to remove the biofilm (Martorano-Fernandes et al., 2020). The number of viable microorganisms was determined by serial dilution of aliquots $\left(10^{-1}\right.$ to $\left.10^{-6}\right)$. The drop technique was used to seed each dilution in Sabouraud Dextrose Agar (SDA) plates (Kasvi, Brazil). Then, the plates were incubated at $37^{\circ} \mathrm{C}$ for 24 hours. The values of counting colony-forming units were multiplied by the serial dilution and converted to a logarithmic scale, expressed in CFU/ mL.

\section{Cell metabolism analysis}

The specimens were incubated with $600 \mu \mathrm{L}$ of RPMI medium containing $10 \%$ methyl-tetrazolium salt (MTT) (Leite et al., 2020) for 3 hours at $37^{\circ} \mathrm{C}$ protected from the light. Then, the medium was removed, $600 \mu \mathrm{L}$ of isopropanol acid $(6 \mathrm{~N}$ $\mathrm{HCl})$ was inserted, and the samples were homogenized. The supernatant was removed, and the absorbance was measured at $570 \mathrm{~nm}$ in a spectrophotometer.

\section{Roughness analysis}

To assess the presence, complexity, and thickness of biofilms, the surface roughness was performed using a profilometer analysis (CCI MP, Taylor Hobson, England) (Martorano-Fernandes et al., 2020). Previous to the measures, the biofilms were fixed in an aqueous solution of $2.5 \%$ glutaraldehyde (Sigma-Aldrich, St. Louis, MO, USA) at $4{ }^{\circ} \mathrm{C}$ for $24 \mathrm{~h}$, and dehydrated at room temperature through increasing cycles of ethanol (50 to 100\%). Subsequently, two aleatory points of the specimen were chosen to measure $(\mu \mathrm{m})$ the Surface Roughness Area (Ra), considering the measurement standards xy $(1024 \times 1024$ pixels $)$, xyz $(512 \times 512$ pixels $)$, and $\mathrm{z}(256 \times 256$ pixels $)$. The speed of $3 \times$ was established, being explored. Greater values of surface roughness mean a more complex biofilm.

\section{Color variation}

Previously on solutions' treatment, the color of discs was measured by a portable LED spectrophotometer. During fourteen days, the specimens were immersed in the solutions, which were replaced every 48 hours. Thus, color variation was assessed in the baseline, seventh, and last treatment days. This analysis was determined according to the CIE-Lab parameter, obtaining values for the color components * $\mathrm{L}$ (light to dark variation), * a (yellow to red variation), and * b (blue to green variation). The specimens' color (E) was determined according to the formula: $\Delta \mathrm{E}=([\Delta \mathrm{L}] 2+[\Delta \mathrm{a}] 2+[\Delta \mathrm{b}] 2)^{1 / 2}($ Porwal 2017). The color change ( $\triangle \mathrm{E}$ ) was the mean of ME1 (baseline), ME2 (7th day), and ME3 (14th day).

\section{Statistical analysis}

The data were analyzed for homogeneity and distribution. In parametric data, it was decided to use the Analysis of Variance (One-way ANOVA) complemented by Tukey. Kruskal-Wallis and Mann-Whitney tests were used for non-parametric data. All data were analyzed using the SPSS software (Statistical Package for Social Sciences, IBM, Chicago, IL, USA), with a significance level of $5 \%(\alpha<0.05)$.

\section{Results}

The cell viability test was performed to access the colony-forming units (CFU / $\mathrm{mL}$ ) of C. albicans after exposure to the substances (Figure 1). Using the biofilm model developed on poly(methyl)methacrylate surfaces, it was found that the 
lowest cell viability was reached by sodium hypochlorite and the highest viability by $0.9 \% \mathrm{NaCl}$. Cinnamaldehyde and $\alpha$ terpineol were able to decrease the number of viable cells compared to $\mathrm{NaCl} 0.9 \%$ by $76 \%$ and $83.2 \%$, respectively $(\mathrm{p}<0.05$ ) (Figure 1). In addition, both substances obtained cell viability similar to sodium hypochlorite ( $p>0.05$ ) (Figure 1).

Figure 1: Cell viability of C. albicans assessed by colony-forming units per milliliter (CFU/ $\mathrm{mL}$ ). Different letters determine the statistical difference (Mann Whitney $\mathrm{p}<0.05$ ). Cinnamaldehyde and $\alpha$-terpineol decrease the number of viable cells compared to $\mathrm{NaCl} 0.9 \%$ by $76 \%$ and $83.2 \%$, respectively ( $\mathrm{p}<0.05$ ). Data shown are from the box plot: each box contains $50 \%$ of the group data; the lower and upper limits represent the 25 th and 75 th percentiles, respectively; bars represent the minimum and maximum values, and the horizontal line inside the box represents the mean.

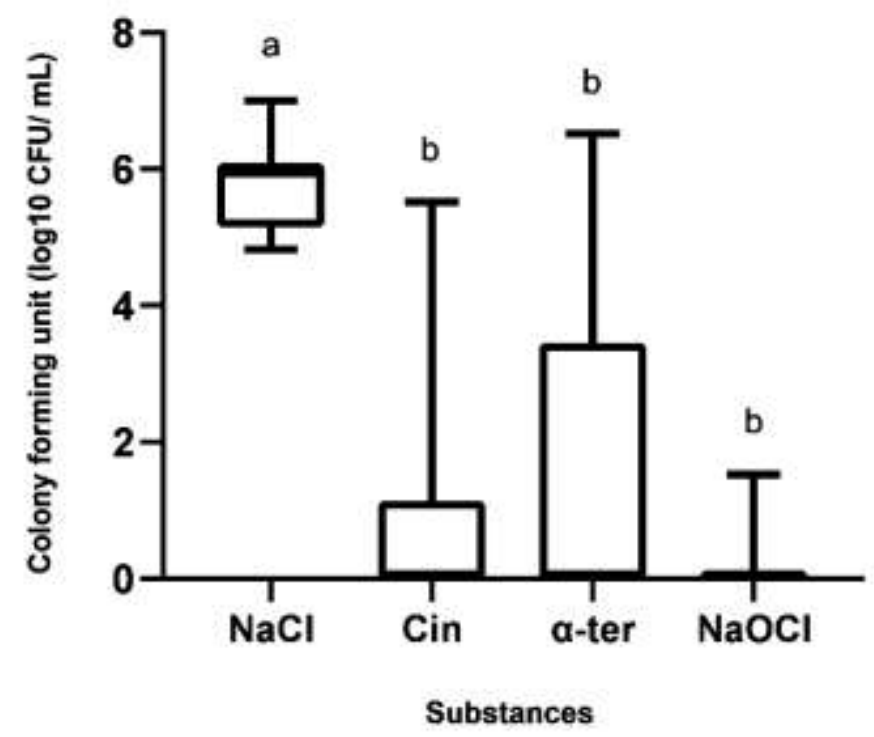

Source: Authors.

Following the results of cell viability, the MTT test findings demonstrated that the highest biofilm metabolism was during exposure to $0.9 \% \mathrm{NaCl}$. In contrast, the lowest metabolism occurred during treatment with sodium hypochlorite (Figure 2). It was also found that cinnamaldehyde, $\alpha$-terpineol, and sodium hypochlorite decreased fungus metabolism by around $70 \%$ when compared to $\mathrm{NaCl}$ 0.9\% ( $\mathrm{p}<0.05$ ) (Figure 2). Although $\alpha$-terpineol induced less biofilm metabolism, it has been significantly different from sodium hypochlorite $(\mathrm{p}<0.05)$. Moreover, biofilms treated with cinnamaldehyde and sodium hypochlorite showed similar metabolism ( $\mathrm{p}<0.05)$ (Figure 2). 
Figure 2: Metabolism of $C$. albicans assessed by methyl-tetrazolium salt (MTT) assay. Different letters determine the statistical difference (Mann Whitney $\mathrm{p}<0.05$ ). Cinnamaldehyde and $\alpha$-terpineol reduced fungi metabolism around $70 \%$ when compared to $\mathrm{NaCl} 0.9 \%(\mathrm{p}<0.05)$. Data shown are from the box plot: each box contains $50 \%$ of the group data; the lower and upper limits represent the 25 th and 75 th percentiles, respectively; bars represent the minimum and maximum values, and the horizontal line inside the box represents the mean.

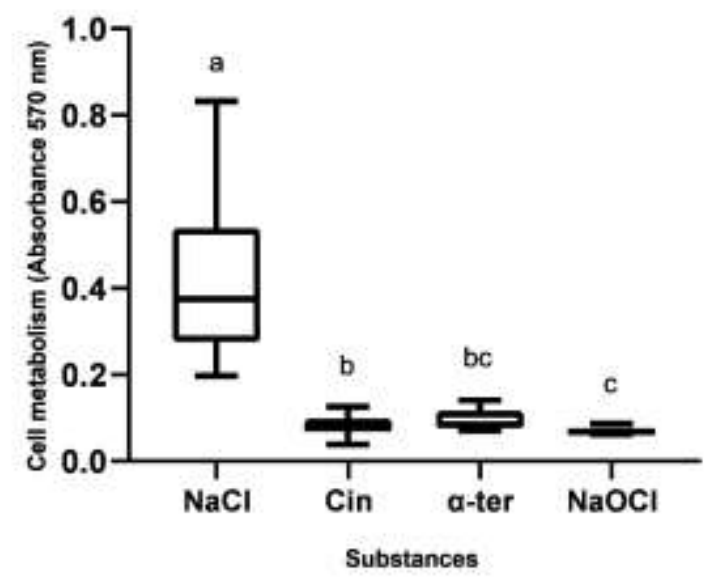

Source: Authors.

The surface roughness was evaluated as an indication of the presence of biofilm (Figure 3). For all specimens, at the baseline (specimens without biofilm), the Surface Roughness Area (Ra) was $0.358 \pm 0.04 \mu \mathrm{m}$. After the treatments, the lowest roughness occurred in the discs treated with cinnamaldehyde. On the other hand, highest was found in the $\mathrm{NaCl} 0.9 \%$. Cinnamaldehyde, $\alpha$-terpineol, and sodium hypochlorite treatments presented significant reductions of roughness compared with the positive control ( $\mathrm{p}<0.05$ ) (Figure 3). This result suggests that the treatments significantly reduced the presence of biofilm.

Figure 3: Representation of the Surface Roughness Area (Ra) indicating presence, complexity, and thickness of biofilm. Different letters determine the statistical difference (ANOVA one way complemented by Tukey $\mathrm{p}<0.05$ ). Cinnamaldehyde, $\alpha$ terpineol, and sodium hypochlorite treatments presented significant reductions of roughness compared with the positive control $(p<0.05)$. Bars represent the means and the error bar the standard deviation.

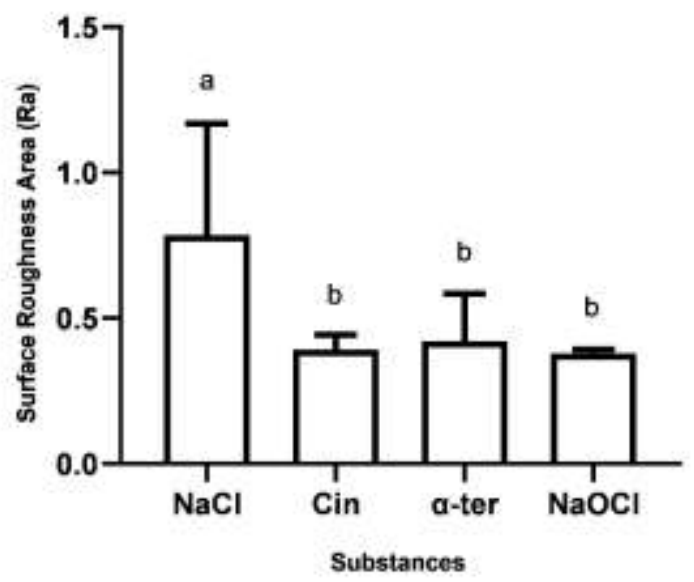

Source: Authors. 
Regarding the evaluation of $\Delta \mathrm{E}$ values obtained from acrylic resin specimens, the sodium hypochlorite showed the highest color change values during the 14 days of assessment (Figure 4). During the same period, the decreased color change was found for specimens exposed to cinnamaldehyde, $\mathrm{NaCl} 0.9 \%$, and $\alpha$-terpineol (Figure 3). Although this color variation of the acrylic resin occurred in all substances tested, there was no significant difference ( $p>0.05)$ (Figure 4).

Figure 4: Distribution of the color variation $(\Delta \mathrm{E})$ obtained from specimens of acrylic resin at the baseline, $7^{\text {th }}$, and $14^{\text {th }}$ days of evaluation (ANOVA one way complemented by Tukey $\mathrm{p}<0.05$ ). There is no statistical difference among the substances.

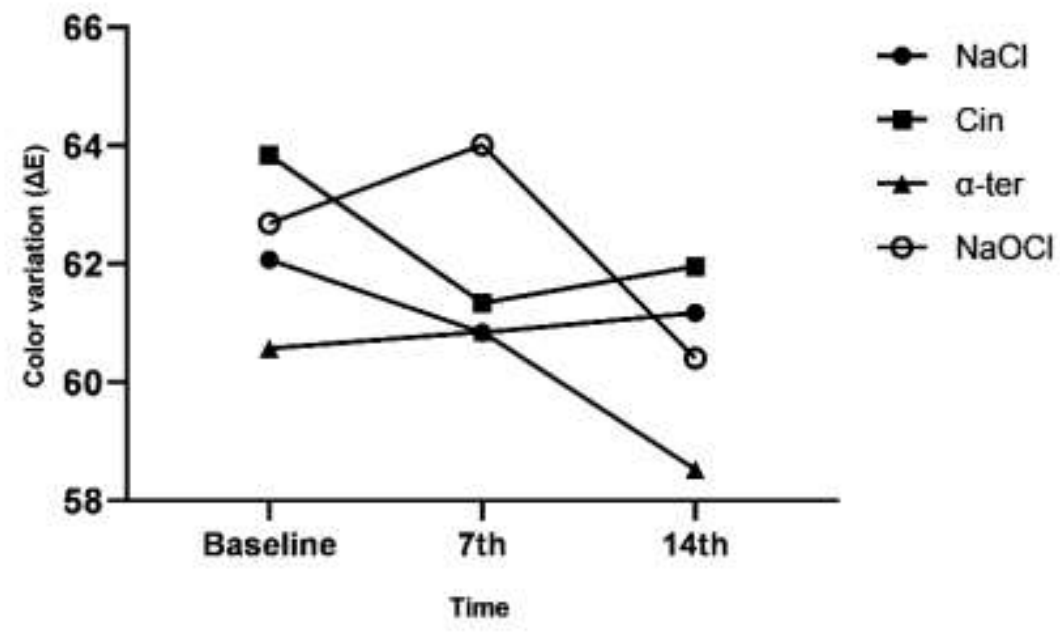

Source: Authors.

\section{Discussion}

Apart from using topical antimicrobials on the palatal mucosa, the denture stomatitis treatment is based on disrupting the biofilm on the removable prosthesis surface (Ribeiro et al. 2019). For this purpose, sodium hypochlorite-based solutions are commonly used for disinfecting the acrylic resin (Skupien et al. 2013; Badaró et al. 2020). However, this agent's use is becoming limited by changes in the material's color (Kurt et al. 2018). Thus, the search for new products has intensified, most in natural sources, to biofilm removal. Overall, our findings showed that cinnamaldehyde and $\alpha$-terpineol effectively remove the biofilm on the denture material similarly to sodium hypochlorite. Besides, these substances had not changed the color of the denture base material.

Both substances reduced over $70 \%$ of the viability and metabolism of fungi cells. In particular, the viable cells decreased $76 \%$ and $83.2 \%$ for the biofilms treated with cinnamaldehyde and $\alpha$-terpineol, respectively. These findings could be explained due to key features of these phytoconstituents' mechanism of action, which is changing the balance of the cells (Chen et al. 2017; Kong et al. 2019). This antifungal effect occurs in a dose-dependent manner. For example, it was suggested that cinnamaldehyde at higher concentrations inhibit the synthesis of enzymes of the membrane, which changes the regulation of intracellular ATP, leading to an imbalance of $\mathrm{K}+$ and $\mathrm{H}+$. This íon depolarization disrupts the cell membrane, thus reaching a death (Shreaz et al. 2013). Another mechanism is related to alterations in the cell morphology through ergosterol damage, which also is an injury in cell integrity (Khan, Ahmad, I \& Cameotra, 2013). As cinnamaldehyde concentrations decrease, this phytoconstituent affects the electrochemical proton gradient necessary for the C. albicans nutrition and influences the cellular division. Consequently, the fungal growth is compromised (Shreaz et al. 2013; Shreaz et al. 2016).

$\alpha$-terpineol activity is related to hydroxyl groups' presence in its chemical structure, making this compound watersoluble. As a result, molecules can penetrate easier and spread through the complex biofilm, thus permeating the cell 
membrane. At relatively low concentrations, $\alpha$-terpineol could change this permeability until it has damage in the homeostasis and, consequently, decreases fungal development. Higher concentrations could lead to a total imbalance in the cells, resulting in osmotic shock (Straede et al. 2007).

Despite the similarity between the cinnamaldehyde and $\alpha$-terpineol mechanisms, some minor differences could explain our results of cell metabolism among the substances. Even though $\alpha$-terpineol leads to low biofilm metabolism, it has been significantly different from sodium hypochlorite, which reaches the lower metabolism. Thus, we could hypnotize that even $\alpha$-terpineol can penetrate the biofilm and leads to an imbalance in the homeostasis, some cells were not totally affected by $\alpha$-terpineol, thus keeping to metabolize. It is possible that higher concentrations could reduce even more cell metabolism.

On the other hand, increase the phytoconstituent concentration introduces a particular concern: cytotoxicity. Although cinnamaldehyde and $\alpha$-terpineol have dose-dependent anti-C. albicans effect, these substances also have dose-dependent cytotoxicity (Murakami et al. 2018; Ramage et al. 2012). A previous investigation showed that cinnamaldehyde has LC50 of 0.2-0.5 mM for RAW264.7 cells (Murakami et al. 2018), whereas $\alpha$-terpineol has cytotoxicity above MIC50 $0.25 \%$ for OKF6TERT2 epithelial cells (Ramage et al. 2012). Notwithstanding, we proposed applying these substances clinically as denture cleansers without contact with the oral mucosa. A possible side effect on the mucosa could be avoided by brushing and washing the dentures to remove any substance' residue on the PMMA. However, to our knowledge, still unclear evaluation of cinnamaldehyde and $\alpha$-terpineol residuals on the acrylic resin. Thus, future studies should evaluate this before the safe use of these substances.

Another relevant question regarding denture cleansers is related to the remaining biofilm on the prosthesis after the treatment. This biofilm could contribute to C. albicans' recolonization (Faot et al. 2014) and consequently keep the disease. Surface roughness results showed a residual biofilm on the PMMA exposed to cinnamaldehyde, $\alpha$-terpineol, and sodium hypochlorite. Thus, even though reducing viable cells and metabolism occurs, the solutions did not wholly remove the biofilm. This finding following previous investigations that evaluated denture cleansers (Faot et al. 2014; Freitas-Fernandes et al. 2014). This could be explained due to the presence of an extracellular matrix of biofilm, which protects them from chemical agents (Gulati and Nobile, 2016). However, of importance, denture cleansers are complementary methods for biofilm disrupting (Axe et al. 2016). An association with mechanical methods, as brushing the prosthesis, would remove the residual biofilms and prevent the recolonization.

Overall our results corroborate with other studies that demonstrated an antifungal effect of cinnamaldehyde and $\alpha$ terpineol (Taguchi et al. 2012; Ramage et al. 2012; Taguchi et al. 2013; Pradebon Brondani et al. 2018; Bakhtiari et al. 2019). Although these findings were promising, somewhat a limitation of this study is related to an evaluation of C. albicans virulence after the treatment with the substances. It is noted that the $C$. albicans virulence is a target point to an ideal denture cleanser. As more virulent, the higher will be the capacity to provoke the disease (Calderone \& Fonzi, 2001; Gulati and Nobile, 2016). Thus, gene expression analysis of virulence factors as adhesins (Als family) and aspartate-proteinases (Sap) should be investigated in the biofilm exposed to cinnamaldehyde and $\alpha$-terpineol. Moreover, the morphological transformation from blastospores into the hyphal stage could also determine this biofilm's virulence.

In addition to had an antifungal effect, a denture cleanser also needs not change the color of the PMMA. Interestingly cinnamaldehyde and $\alpha$-terpineol did not modify the color of the acrylic resin after seven and fourteen days. Aesthetics is one of the most characteristics willing by subjects wearing dentures (Zou and Zhan, 2015). Therefore, changes in the acrylic resin color during the use of denture cleansers could avoid these users from using the prosthesis. In contrast with the literature, our findings showed that sodium hypochlorite also did not change the color of the PMMA. These results could be explained due to the brief time of evaluation (fourteen days). A previous investigation showed changes in the color of PMMA discs exposed to $\mathrm{NaOCl}$ after 180 days of assessment (Porwal et al. 2017). Therefore, future studies also should consider investigating the 
cinnamaldehyde and $\alpha$-terpineol PMMA color change for long periods.

\section{Conclusion}

Altogether, our results have shown an antifungal effect of cinnamaldehyde and $\alpha$-terpineol without affecting the acrylic resin color. Although these results are promising, future studies should consider evaluating cinnamaldehyde and $\alpha$ terpineol in a complex biofilm containing oral bacteria, such as Streptococcus sp. From a clinical viewpoint, natural medicine is an excellent strategy in treating denture stomatitis because it has a low cost and the wide availability of these compounds in many plants and fruits. Therefore, cinnamaldehyde and $\alpha$-terpineol are potential substances to use as denture cleansers.

\section{Acknowledgments}

The authors thank the Conselho Nacional de Desenvolvimento Científico e Tecnológico - Brazil (CNPq) for providing scholarship to the first author

\section{References}

Almeida, L., Paula, J. F., Almeida, R. V., Williams, D. W., Hebling, J., \& Cavalcanti, Y. W. (2016). Efficacy of citronella and cinnamon essential oils on Candida albicans biofilms. Acta odontologica Scandinavica, 74(5), 393-398.

Arruda, C., Salles, M. M., Badaró, M. M., Sorgini, D. B., Oliveira, V. C., Macedo, A. P., Silva-Lovato, C. H., \& Paranhos, H. (2018). Evaluation of biofilm removal and adverse effects on acrylic resin by diluted concentrations of sodium hypochlorite and Ricinus communis solutions. Gerodontology, $10.1111 /$ ger.12348.

Axe, A. S., Varghese, R., Bosma, M., Kitson, N., \& Bradshaw, D. J. (2016). Dental health professional recommendation and consumer habits in denture cleansing. The Journal of prosthetic dentistry, 115(2), 183-188.

Badaró, M. M., Bueno, F. L., Arnez, R. M., Oliveira, V. C., Macedo, A. P., de Souza, R. F., Paranhos, H., \& Silva-Lovato, C. H. (2020). The effects of three disinfection protocols on Candida spp., denture stomatitis, and biofilm: A parallel group randomized controlled trial. The Journal of prosthetic dentistry, 124(6), 690-698.

Bakhtiari, S., Jafari, S., Taheri, J. B., Kashi, T., Namazi, Z., Iman, M., \& Poorberafeyi, M. (2019). The Effects of Cinnamaldehyde (Cinnamon Derivatives) and Nystatin on Candida Albicans and Candida Glabrata. Open access Macedonian journal of medical sciences, 7(7), 1067-1070.

Calderone, R. A., \& Fonzi, W. A. (2001). Virulence factors of Candida albicans. Trends in microbiology, 9(7), 327-335.

Cavalcanti, Y. W., Wilson, M., Lewis, M., Williams, D., Senna, P. M., Del-Bel-Cury, A. A., \& da Silva, W. J. (2016). Salivary pellicles equalise surfaces' charges and modulate the virulence of Candida albicans biofilm. Archives of oral biology, 66, 129-140.

Chen, B. J., Fu, C. S., Li, G. H., Wang, X. N., Lou, H. X., Ren, D. M., \& Shen, T. (2017). Cinnamaldehyde Analogues as Potential Therapeutic Agents. Mini reviews in medicinal chemistry, 17(1), 33-43.

Groot, A. C., \& Schmidt, E. (2016). Tea tree oil: contact allergy and chemical composition. Contact dermatitis, 75(3), 129-143.

Doyle, A. A., \& Stephens, J. C. (2019). A review of cinnamaldehyde and its derivatives as antibacterial agents. Fitoterapia 139, 104405.

Duyck, J., Vandamme, K., Krausch-Hofmann, S., Boon, L., De Keersmaecker, K., Jalon, E., \& Teughels, W. (2016). Impact of Denture Cleaning Method and Overnight Storage Condition on Denture Biofilm Mass and Composition: A Cross-Over Randomized Clinical Trial. PloS one, 11(1), e0145837.

Faot, F., Cavalcanti, Y. W., Mendonça e Bertolini, M. d., Pinto, L., da Silva, W. J., \& Cury, A. A. (2014). Efficacy of citric acid denture cleanser on the Candida albicans biofilm formed on poly (methyl methacrylate): effects on residual biofilm and recolonization process. BMC oral health, $14,77$.

Figuerôa, R., Conterno, B., Arrais, C., Sugio, C., Urban, V. M., \& Neppelenbroek, K. H. (2018). Porosity, water sorption and solubility of denture base acrylic resins polymerized conventionally or in microwave. Journal of applied oral science: revista FOB, 26, e20170383.

Freitas-Fernandes, F. S., Cavalcanti, Y. W., Ricomini Filho, A. P., Silva, W. J., Del Bel Cury, A. A., \& Bertolini, M. M. (2014). Effect of daily use of an enzymatic denture cleanser on Candida albicans biofilms formed on polyamide and poly (methyl methacrylate) resins: an in vitro study. The Journal of prosthetic dentistry, 112(6), 1349-1355.

Gendreau, L., \& Loewy, Z. G. (2011). Epidemiology and etiology of denture stomatitis. Journal of prosthodontics: official journal of the American College of Prosthodontists, 20(4), 251-260.

Gulati, M., \& Nobile, C. J. (2016). Candida albicans biofilms: development, regulation, and molecular mechanisms. Microbes and infection, 18(5), 310-321.

Hannah, V. E., O'Donnell, L., Robertson, D., \& Ramage, G. (2017). Denture Stomatitis: Causes, Cures and Prevention. Primary dental journal, 6(4), 46-51. 
Khan, M. S., Ahmad, I., \& Cameotra, S. S. (2013). Phenyl aldehyde and propanoids exert multiple sites of action towards cell membrane and cell wall targeting ergosterol in Candida albicans. AMB Express, 3(1), 54.

Kong, Q., Zhang, L., An, P., Qi, J., Yu, X., Lu, J., \& Ren, X. (2019). Antifungal mechanisms of $\alpha$-terpineol and terpene-4-alcohol as the critical components of Melaleuca alternifolia oil in the inhibition of rot disease caused by Aspergillus ochraceus in postharvest grapes. Journal of applied microbiology, 126(4), $1161-1174$.

Kurt, A., Erkose-Genc, G., Uzun, M., Sarı, T., \& Isik-Ozkol, G. (2018). The Effect of Cleaning Solutions on a Denture Base Material: Elimination of Candida albicans and Alteration of Physical Properties. Journal of prosthodontics: official journal of the American College of Prosthodontists, 27(6), 577-583.

Leite, K. F., Martins, M. L., de Medeiros, M. M., Bezerra, N. V., Brito, C. M., de Almeida, L. F., \& Cavalcanti, Y. W. (2020). Red propolis hydroalcoholic extract inhibits the formation of Candida albicans biofilms on denture surface. Journal of clinical and experimental dentistry, 12(7), e626-e631.

Martins, M. L., Leite, K., Pacheco-Filho, E. F., Pereira, A., Romanos, M., Maia, L. C., Fonseca-Gonçalves, A., Padilha, W., \& Cavalcanti, Y. W. (2018). Efficacy of red propolis hydro-alcoholic extract in controlling Streptococcus mutans biofilm build-up and dental enamel demineralization. Archives of oral biology, 93, 56-65.

Martorano-Fernandes, L., Cavalcanti, Y. W., \& de Almeida, L. (2020). "Inhibitory effect of Brazilian red propolis on Candida biofilms developed on titanium surfaces". BMC complementary medicine and therapies, 20(1), 104.

Mayer, F. L., Wilson, D., \& Hube, B. (2013). Candida albicans pathogenicity mechanisms. Virulence, 4(2), 119-128.

Mehta, P., Shah, R., Lohidasan, S., \& Mahadik, K. R. (2015). Pharmacokinetic profile of phytoconstituent(s) isolated from medicinal plants-A comprehensive review. Journal of traditional and complementary medicine 5(4), 207-227.

Murakami, Y., Kawata, A., Suzuki, S., \& Fujisawa, S. (2018). Cytotoxicity and Pro-/Anti-inflammatory Properties of Cinnamates, Acrylates and Methacrylates Against RAW264.7 Cells. In vivo (Athens, Greece), 32(6), 1309-1322.

Paranhos, H., Peracini, A., Pisani, M. X., Oliveira, V., de Souza, R. F., \& Silva-Lovato, C. H. (2013). Color stability, surface roughness and flexural strength of an acrylic resin submitted to simulated overnight immersion in denture cleansers. Brazilian dental journal, 24(2), 152-156.

Pellizzaro, D., Polyzois, G., Machado, A. L., Giampaolo, E. T., Sanitá, P. V., \& Vergani, C. E. (2012). Effectiveness of mechanical brushing with different denture cleansing agents in reducing in vitro Candida albicans biofilm viability. Brazilian dental journal, 23(5), 547-554.

Pereira, A. S., Shitsuka, D. M., Parreira, F. J., Shitsuka, R. (2018). Metodologia da Pesquisa Científica. Santa Maria, RS: Núcleo de Tecnologia Educacional NTE.

Porwal, A., Khandelwal, M., Punia, V., \& Sharma, V. (2017). Effect of denture cleansers on color stability, surface roughness, and hardness of different denture base resins. Journal of Indian Prosthodontic Society, 17(1), 61-67.

Pradebon Brondani, L., Alves da Silva Neto, T., Antonio Freitag, R., \& Guerra Lund, R. (2018). Evaluation of anti-enzyme properties of Origanum vulgare essential oil against oral Candida albicans. Journal de mycologie medicale, 28(1), 94-100.

Ramage, G., Milligan, S., Lappin, D. F., Sherry, L., Sweeney, P., Williams, C., Bagg, J., \& Culshaw, S. (2012). Antifungal, cytotoxic, and immunomodulatory properties of tea tree oil and its derivative components: potential role in management of oral candidosis in cancer patients. Frontiers in microbiology, 3, 220.

Ribeiro, A. B., de Araújo, C. B., Silva, L., Fazan-Junior, R., Salgado, H. C., Ribeiro, A. B., Fortes, C. V., Bueno, F. L., de Oliveira, V. C., de F O Paranhos, H., Watanabe, E., \& da Silva-Lovato, C. H. (2019). Hygiene protocols for the treatment of denture-related stomatitis: local and systemic parameters analysis a randomized, double-blind trial protocol. Trials, 20(1), 661.

Shreaz, S., Bhatia, R., Khan, N., Muralidhar, S., Manzoor, N., \& Khan, L. A. (2013). Influences of cinnamic aldehydes on $\mathrm{H}^{+}$extrusion activity and ultrastructure of Candida. Journal of medical microbiology, 62(Pt 2), 232-240.

Shreaz, S., Wani, W. A., Behbehani, J. M., Raja, V., Irshad, M., Karched, M., Ali, I., Siddiqi, W. A., \& Hun, L. T. (2016). Cinnamaldehyde and its derivatives, a novel class of antifungal agents. Fitoterapia, 112, 116-131.

Skupien, J. A., Valentini, F., Boscato, N., \& Pereira-Cenci, T. (2013). Prevention and treatment of Candida colonization on denture liners: a systematic review. The Journal of prosthetic dentistry, 110(5), 356-362.

Souza, R. F., Silva-Lovato, C. H., de Arruda, C. N., Regis, R. R., Zanini, A. P., Longo, D. L., Peracini, A., de Andrade, I. M., Watanabe, E., \& Paranhos, H. F. (2019). Efficacy of a propolis solution for cleaning complete dentures. American journal of dentistry, 32(6), 306-310.

Straede, A., Corran, A., Bundy, J., \& Heinisch, J. J. (2007). The effect of tea tree oil and antifungal agents on a reporter for yeast cell integrity signalling. Yeast (Chichester, England), 24(4), 321-334.

Taguchi, Y., Hasumi, Y., Hayama, K., Arai, R., Nishiyama, Y., \& Abe, S. (2012). Effect of cinnamaldehyde on hyphal growth of C. albicans under various treatment conditions. Medical mycology journal, 53(3), 199-204.

Taguchi, Y., Hasumi, Y., Abe, S., \& Nishiyama, Y. (2013). The effect of cinnamaldehyde on the growth and the morphology of Candida albicans. Medical molecular morphology, 46(1), 8-13.

Zou, Y., \& Zhan, D. (2015). Patients' expectation and satisfaction with complete denture before and after the therapy. Vojnosanitetski pregled, 72(6), 495-498. 